convolution in the monkey, and their results filled up a gap in the well-known work of Ferrier in that they were able to show that removal of certain areas, the excitation of which had previously caused movements of muscles of the trunk, \&c., on both sides led to paralysis of muscles of the trunk of such a "degree that the animal was unable to stand. By removal of the frontal lobes no paralysis of voluntary movements were obtained. These results were in opposition to those of Munk, of Berlin.

Or a of Monotremes. - The President stated that he had a most important announcement to make. He had just received a cablcgram from Sydney, from Prof. Liversidge, announcing that Mr. Caldwell, the Balfour Student, who was sent out to Australia to investigate the mysteries in connection with the mammals of that country, had discovered that the Monotremes were oviparous. He did not consider that a more important telegram in a scientific sense had ever passed through the submarine cables before. The Monotremes formed two families characterised by the duckbilled Platypus and an animal which was known to the Australians as the ant-eater. These were the lowest forms of mammals, and it had never been known how they produced their young. The extraordinary discovery was now made that these mammals laid eggs, and that the development of these eggs bore a close resemblance to the development of the eggs of the Reptilia. This discovery proved that these animals were more closely connected with the Sauropsida than with the Amphibia.

On Sensory Nerve-Sacs in the Skin of Amiurus, a Siluroid Fish; and On the Function of the Air-Bladder in Amiurus, and its Relationship to the Auditory Organ, by Prof. R. Ramsay Wright. $-\mathrm{He}$ referred to the numerous species in North American fresh waters, and their remarkable uniformity, almost all belonging to one genus, Amiurus, while tropical fresh waters teem with many different genera differing extremely fr $\mathrm{m}$ each other in form. All the species, however, live in muddy waters, and, to make up for the want of the powerful eyesight which characterises the salmon, are provided with an exceedingly sensitive skin and with special tactile appendages on the head. The lecturer described the already known forms of sensory organs in the skin, and then pointed out that certain structures recalling the nerve-sacs of ganoid fishes, like the sturgeon and gar-pike, are scattered all over the body from head to tail, and both on the upper and lower surfaces. This diffusion of these organs is of interest as indicating probably an ancient type of their arrangement. The second point touched upon was the function of the air-bladder and its relationship to the auditory apparatus. Prof. Wright believes the fish becomes sensible of alterations in the pressure of the surrounding water in the auditory apparatus, and suggested that the air-bladder is also an important channel through which sounds are communicated to the terminal organs of the auditory nerve.

In the discussion which followed Prof. Alfred Haddon of Dublin confirmed the latter point, and suggested that this particularly delicate apparatus for receiving sounds was present on account of the fact that tropical Siluroids, at any rate, are capable of producing sounds by means of a stridulating apparatus, some forms of which he had himself clescribed.

\section{Section H-Anthropol.ogy}

Mr. Horatio Hale read an interesting paper On the Origin of Wampum. He said that amongst the Indians it represented mammon, or money, and was equally valued. It had once been actually accepted in Massachusetts and New York as legal currency, owing to lack of silver, and was largely used in the Indian trade. Wampum consisted of a kind of bead or shell, but must not be confounded with the cowries of the East. Indians on the sea-coast drove a large trade in this article, and Long Island was a mine of wealth. The word wampum was of Algonquin origin, and meant white. The speaker explained the various uses to which this material was put. It was generally used in strings and belts, and at the great Iroquois ceremonies it was considered indispensable. Black wampum was more valuable than white. Of the many thousands of bclts that had been known to exist during the last three centuries, scarcely fifty remained, and $\mathrm{Mr}$. Hale regretted the dull indifference that had been displayed by the Americans with regard to this interesting and valuable material, valuable as forming a chronicle of the tribes who manufactured the belts. Mr. Hale exhibited an historical belt of wampum, composed of white beads, with four black squares, which, he said, represented four towns. This belt, he said, was one hundred and sixty years old. Another and still more remar able belt was also shown by the speaker, who explained the emblems upon it, which, he said, were intended to represent the signs of the Christian religion. There were three crosses representing the Trinity, a lamb, executed in a primitive manner, and a dove. These objects, Mr. Hale said, had been evidently suggested to the Indian artist, who had done his best to represent them, but he said that his artistic powers should not be judged by this specimen. The speaker also displayed some strings of beads, and said that these were used in the Indian chants, the beads recalling certain verses to the singers. Mr. Hale showed to the Section a photograph of some Indian chiefs of the six nations who had met at Brantford and explained to him the meaning of their wampum belts. Shell beads, he said, were used in large quantities by the mound-builders, and he argued that it was probable that the art of manufacturing this medium had descended to the modern tribes from their more advanced ancestors. Some beads, which had been found in an enormous burial-place in Orillia county by Mr. Hirschfelder, were shown by Mr. Hale, who said that these were undoubtedly used by the Hurons. Crossing the Rocky Mountains, he said that wampum woukl be found in actual use, the material itself and the labour devoted to its ornamentation making it extremely valuable. Being susceptible of a high polish, it forms very handsome ornaments, and is better adapted for this purpose than for currency, for which it is cumbersome. Speaking of the amount of shell money possessed by the primitive Indians, Mr. Hale said that the average man owned about one hundred dollars' worth, that being, he said, about the value of two women, two grizzly bear skins, twenty-five cinnamon bear skins, or three ponies. Mr. Hale remarked on the districts in which wampum was found, and quoted some sentences from a work of his own with regard to the discovery of wampum in the Kingsmill Islands of Micronesia in the Pacific Ocean. There, he said, he saw strings of alternate wooden and shell beads. He exhibited to the Section specimens of beads from the Kingsinill Islands and from California, some of these having lost their lu tre from the long time which they had been buried in a grave. Mr. Hale made some interesting remarks upon the history of Chinese money or "cash" tracing its origin to the tortoise-shell disks used in earlier times. Mock money, he said, was sometimes burnt at sacrifices, as the Californian Indians burnt their shell money at funerals. $\mathrm{He}$ traced the passage of this currency between Asia and America, showing how it could have been brought from one district to another. It was used, he said, by Indians in Eastern North America, those in California, the inhabitants of Micronesia, and the Chinese. He thought that the monetary system was indigenous to China, and that by early intercourse it had been conveyed to this continent. He noticed the fact that Chinese junks and Micronesian prows may have been wrecked on the western shores of America, and that their crews may have introduced the system of shell money amongst the Indians.

Major J. W. Powell read a paper on The Marriage Lauss of the North American Tribes. In the course of his observations, the speaker remarked upon the custom of burying articles with the dead. There were two classes of property amongst the Indians, communal, or that belonging to the tribe, and personal, or that belonging to the individual. In order to prevent controversy the latter was buried with its owner. W'ith regard to the marriage laws, Major Powell said there were many strange customs. For instance, in some tribes, marriages were arranged by officers of the tribe, and the choice of wife or husband was limited to certain groups of persons. Marriage was therefore not by personal choice, but by legal appointment. But marriage could be performed by elopement, or running away, when, if the couple could remain in safety from detection and punishment until after the day of jubilee, or the day when all offences are considered forgiven, then that marriage would be considered legal. Wives could also be obtained by trial of battle, a contest of some kind, when the woman became the helpmate of the victor. There was also marriage by capture. The methods of obtaining a wife were so common that the custom of marriage by legal appointment was much neglected. But though this was the legal and proper method, the others had become Jegalised by long custom, and now the capture, contest, or elopement were merely simulated.

Mr. C. A. Hirschfelder of Toronto, as representative of the Numismatic and Antiquarian Society of Montreal, read a paper On Prehistoric Remains in Canada. The ancient remains of 
Canada have, as yet, been by no means satisfactorily cxamined, and consequently but superficially described; and although we have no stone ruins, still that does not detract from the intere.t of the prehistoric works, found scattered over various sections of this country, which are well worthy of a thorough scientific examination. The forts, which were built principally of earth, although stone was not unfrequently used to some extent in their construction, are particularly interesting from two points of view-viz. the almost perfect symmetrical shape, and the advantageous positions which were invariably chosen. As to the firstnamed feature, they bear a striking resemblance to the ancient earthworks of the Western States, by which some writers have endeavoured to prove that the authors of those works must have been advanced in certain sciences. As to the situation of these forts, their ancient builders seem to have carefully studied localities, and to have fully appreciated the advantages to be gained thercby, as the situations chosen were invariably such as either to command a view for a long distance over the country, or, if near the water, to be so constructed that a fleet of canoes could be seen a long distance away, so that sudden attacks by water would be impracticable. The forts were generally made either circular or oval, although one or two surveyed were crescent or semicircular, the form probably depending upon the lay of the land; and it is very singular that there has not been, to my knowledge, a single fort discovered in Canada which even approaches a square. Entrenchments seem to have been a not uncommon mode of defence, and have every appearance of being anterior to the wall or embankment forts; the largest one surveyed was half a mile in circumference, of a circular form, and, judging by counting the concentric rings of trees growing right in the ditch, which must have grown after the fort was constructed, also by decayed vegetable-matter and other evidences, was computed to be from 800 to 1000 years old. Ancient burial-places may be classed u..der three heads-mounds, ossuaries, and single graves. Mounds are not of frequent occurrence in Canada, and all which have so far been examined have contained human bones, proving that they were used as burial repositories. These tumuli (if they may be so termed) are not by any means large; they generally measure about 100 feet in circumference, and are only about 5 feet high. The dead seem to have been buried without any regular system, each mound containing from six to twelve bodies. The ossuaries are probably the most interesting remains we have. They consist of round symmetrical holes dug to the required depth, and into which the bodies were promiscuously deposited; sume of the larger ones contain the remains of several thousand bodies. The single graves are the most ordinary remains we have, and are generally found on high ground, a hill-top being a favourite site. In dwelling upon sepulture, I trust to be able to show clearly that the burial of articles with the dead was not so much a religious act as a mark of respect to the dead. The archrological relics of Canada have never been fully described, and are deserving of a higher rank, in a scientific sense, than has as yet been accorded them. We have a grand field to work in, and the articles we find well repay us for the trouble taken. The aborigines of America are undoubtedly the fathers of smoking, and the elaborate workmanship which was bestowed upon their pipes shows the important place it took in their every-day life. There are no articles found which so well portray the aboriginal ingenuity as the pipes. Animals, birds, reptiles, and the human physiognon y are all carved upon the bowls and stems with life-like accurateness. Many specimens found would trouble a clever artisan of the present day to duplicate, allowing him all the modern tools to work with, because stones, tools, ornaments of various kinds, \&c., were also manufactured with a precision simply perfect ; and, strange to say, it scems to have been a matter of little moment whether they worked the hardest or softest qualities. Pottery, shell, and bone were extensively used in the manufacture of articles for their every-day life, whether for ornaments or necessary utensils ; copper was also utilised to some extent, principally for tools, ornaments, and sword-blades; the ore was merely pounded into the required shape. Shells, which must have been brought a distance of nearly 2000 miles, are sometimes found in graves, evidencing the extraordinary fact that a trade must have been carried on between the aborigines of the north and those of the south, which, extending over such a vast distance, and with their primitive mode of travelling, must have made the articles exchanged of great value. The wampum was probably nearly altogether carved from these foreign shells.

Major J. W. Powell, U.S.A., read a paper on The Classification of North American Languages. Major Powell said that in his remarks he would confine himself to those languages which possessed at least a thousand words. Pointing to a map of the United States on which the distribution of the languages was marked, the speaker said that there were four great distinctive tongues on the continent, the Aligonquian, the Shoshonian, the Siouan, and the Athabascan. The classification of these languages was impossible, he said, but we could classify the arts, the habits, the philosophy of the peoples. He remarked on the fact that grammars and dictionarics, books, and even newspapers, were published in some of the Siouan languages, the Dakotan for instance. For the purpose of convenience and study of the North American languages, rules had been drawn up and adopted, which rules were read and commented upon by Major Powell. One of these was that family names should not be recognised if they consister of more than one word, and another that all tribal names should terminate in "an," as Aligonquian and Shothonian. These were highly necessary to prevent confusion. The speaker described the difficulty he had experienced in classifying the different names during the past fifteen years, and remarked that the affinities of various languages were not yet practically determined. Within a year, the work, he hoped, would be completed, as far as the United States were concerned, but it would take some years before the work for the North American continent was concluded. Four gentlemen were now in the field engaged in collecting vocabularies for this purpose. Remarking on the likeness between the words "kayak" and "caique," Major Powell said that it could be imagined how extremely difficult it was to decide upon such a matter, there being, for instance, eighty languages in North America which possess no affinities with each other. Grammatic affinities might exist, but none closer. He thought that early arts could not be relied upon to connect peoples. Institutions and languages were more valuable and lasting helps to classify nations, the latter especially so. Finally, the speaker said that, as there were eighty different stocks of languages and the same number of mythologies, it would be a long time before their labours were completed.

Mr. Rosefeldt observed that, although he had lived among the Indians for some years, he had never met with an Indian who could pronounce the letter $R$. In this they were like the Chinese, and therefore might have migrated into America by way of Bchring Straits. He related an incident which occurred during his residence amongst the Indians. One of them asking him to what family he (the speaker) belonged, Mr. Rosefeldt replied, the fox, as this animal occurred in his coat-of-arms. The Indian said, "'Then I must be your 'pickanniny," " or son, showing the figure of a snake on his arm, "as the snake is the son of the fox!" This showed that the Indians imagined that they derived their descent from various animals.

Mrs. Erminie A. Smith read a paper On the Customs and Language of the Iroquois. Some years ago Mrs. Smith was received into the tribe of the Tuscaroras, and adopted as a sister by one of the chiefs of that nation. An assemblage was held to do honour to this auspicious event, and a handsome beadwork dress was prepared for Mrs. Smith. The chief who adopted her being one of the "Bear" family, she also became a Bear. Mrs. Smith made some interesting remarks upon the costumes and upon the gambling habits of the Indians, and showed some of the silver brooches used by them as stakes in the games. A hair "waterfall," composed of some five hundred scalps joined together, was exhibited, as well as the temperance banner of the Tuscaroras; this bore a rude representation of the American eagle destroying the demon of intemperance, with six stars of the six nations, and figures of the animals which are symbols of the tribes. Noticing the construction of the Iroquoian language, Mrs. Smith said that there were two so-called genders, noble and ignoble ; the former comprised God, men, and angels, and the latter demons, the lower animals male and female, inanimate objects, and "women, children, and other chattels."

Mr. F. H. Cushing read a paper On the Development of Industrial and Ornamental Art among the Zunis of New Mexico. The speaker's remarks were illustrated by numerous specimens of pottery and other kinds of work done by the Indians. $\mathrm{Mr}$. Cushing said that by adoption of the Zuni language, customs, habits of living, and costume, to the minutest particular, he had been enabled to obtain a vast amount of information regarding these people-descendants, as he said, of the "Pueblo Indians." The word "Pueblo," he explained, was applied to a nation who lived in communal dwellings. He brought forward evidence, linguistic and otherwise, to prove the descent of the Zunis from 
these races. He described the causes that led to the architecture of the petty clans, such as a need of protection which induced them to seek the caves in cliffs, and traced the history of the "Pueblo" or communal dwellings. The art of pottery, he said, was practised in the "Pueblo" district to a very great extent. He gave an interesting account of the formation of the Zuni gourds, or water vessels, showing how they were covered with wickerwork in order to preserve them. Basket-work vessels were also used, these latter being covered with a preparation of clay in order to prevent the escape of the contents. Mineral coal was used in the manufacture of earthenware vessels and also upon the corrugated surface given to the bowls. A curious fact with regard to the food utensils of the $Z$ unis was that they regard the bowls they make as possessing $\mathrm{s}$ ) mething in the nature of life or spirit. They place food and water near the vessel, and as a woman completes it she imagines she has made something like a created being. The different sounds made by the pots as they are struck, or as their contents boil, for instance, are believed to be the voices of the beings which are associated with the vessels. Apertures or blank spaces are left for the escape of this spirit. A Zuni woman, as she closes the apex of a pointed clay vessel, turns her eyes away, and says that it is "fearful" to watch this operation. She thinks that if she knowingly (that is in her sight) closes this orifice, which she regards as a source of life, the source of life in herself may be closed, and that she may be debarred from the privilege of child-bearing. Other evils are also expected to follow if she does not turn away as she completes the vessel's shape by closing the apex. The Zunis, in representing animals, always show a kind of line or passage leading from the throat to the heart, and cannot be induced to dispense with this line in any pictorial representation of animals. In conclusion, the reader of the paper referred to the probable origin of the shapes used in the pottery of America.

Dr. Daniel Wilson then read a paper on The Huron-Iroquois, a Typical Race of Amerian Aborigines. - He remarked upon the natural boundaries of countries, and the difficulties they presented to nomadic races. East of the Rocky Mountains the ethnology was comparatively simple. There were but three great raccs or families, the Iroquois, the Algonquin, and the Athabascan. The Blackfeet were, however, a different race, and possessed different characteristics. West of the Rocky Mountains the subdivisions were more numerous, but not so large. He mentioned the valuable though imperfect vocabulary of Jacques Cartier, which showed something of the language used by the Iroquois or Six Nations. He cntmerated the nations of which this confederation was composed, and remarked upon the localities in which they lived. The original native population of this part of Canada, Dr. Wilson said, was the Huron-Iroquois. They were found in the valley of the St. Lawrence by the early explorers. Some of them had been driven out and had returned to Canada at the time of the American Revolution, in one case, he said, bringing with them the silver communion service given to the Mohawk church by Quecn Anne, and now used in the Tuscarora church. Dr. Wilson referred to the Indians of Lorette and of Anderdon as representing the ancient type of Hurons. These people, he said, believed that their ancestors came from the ncighbourhood of the "great sea" or the Atlantic. The speaker then showed a skull, probably that of a Hochelaga Indian, which had been found near this spot. This, he said, presented all the types of the IIuron race. He contended that it was a Huron people that had becn found here by Jacques Cartier, though he said that the funeral customs of that nation did not seem to have been practised in this district. These funeral customs, and the ceremony of the "feast of the dead" were described in an interesting manner by the Profes or. Dr. Wilson remarked upon the want of knowlege of metallurgy shown by the inhabitants of North America, and the general slow progress in civilisation which was displayed by these people. Copper in large quantities was ready to their hand, but no trace of its being used was found, and the application of fire to the metal sccmed not to be thought of. $\mathrm{Hc}$ noticed the earth-works of the Ohio Valley, which he said should be visited by the firitish visitors before their return to Europe. He concluded by referring to the influence that the half breed population of Manitoba might have in future times upon the inhabitants.

Dr. 'Tylor, after expressing his thanks to Prof. Wilson for his communication, called upon Mr. Horatio Hale to make some remarks upon the subjects on whichthe last speaker had touched. This Mr. Hale did, saying that the tradition amongst the If urons was that their ancestors had moved westward from the districts in which they were found by Cartier. With regard to the question of the language of the Hurons as compared with that of the Iroquois, Mr. Hale read a letter from the Hon. Judge Force, of Cincinnati, who had studicd this subject. Mr. Hale also made some interesting observations on the difference of pronunciation between these people, his remarks being listened to with deep attention.

Prof. G. Lawson read a paper on Food Plants used by the Indians. The Professor began by remarking on the various berries that were found on this continent, as wcll as the numbers of nut-bearing trees. He showed that the wants of the aborigines would be supplied by the natural products of the woods and fields, and spoke particularly of the wild potato of Nova Scotia, which was so well known among the Indians. Other plants noticed were the bean, fields planted with this vegetable being found by Columbus and by Jacques Cartier, and maize, which was also much used. Beans were grown among the Indian corn, which formed the main crop. Evidence showed that plants like mol n*, pumpkins, and others of the same nature were cultivated by the Indians. Columbus, in r492, found these plants surrounding Indian villages in such a condition as proved that they were cared for.

Lieut. A. W. Greely exhibited a collection of photographs of Esquimaux relics.

Lieut. P. H. Ray read a paper On the Habi's and Customs of the Inu of the Western Shore and Point Barrow. Many of the natives had been measured, and it was found that the tallest height was 5 feet Io inches, and the lowest 5 feet $I$ inch. This was mu h higher than the natives of Greenland. Their powers of endurance were wonderful. Marriage laws they had none : the contract was severed at will. They never quarrelled or entered upon any controversy, and were extremely kind to their parents. Lieut. Ray described the manner in which these people prepared their food for travelling, and in which they captured the reindecr and the seal. Though they did not believe in a future existence, they wcre intensely superstitious, as Lieut. Ray found when he learned their language, and they paid great veneration to the oldest of their wornen. $\mathrm{He}$ thought these people the most primitive that white people had cver come in contact with.

Mr. R. Law read a paper by himself and Mr. I. Horsfall, On Some Small Flint Implements found beneath Peat on Several Elevated Puints of the Pennine Chain lying between Huddersfield and Oldham.-Mr. Law introduced his subject by saying that, though perhaps of a local nature, it might be interesting. In the course of his paper he said that the fint implements which had been discovered had been submitted to competent authorities, and it was considered that they were the smallest ever discovered in England. They were supposed to have been carving implements, and some of them were not more than one inch in length and a quarter of an inch in breadth, while they were carefully marked and chipped on the edges. The spealker concluded by describing the moorland country and geological character of the soil in which these implements were found.

\section{SCIENTIFIC SERIALS}

THE Fournal of the Franklin Institute for August contains :-Wire triangular truss, by Chas. J. Quetil, C. and M.E. (illustrated). - New British standard wire gauge.- Report on the trial of the "City of Fall River," by J. E. Sague, M.E., and J. B. Adger, M.E., with an introduction by Prof. R. H. Thurston (continued from vol. cxviii. p. 74, illustrated, and with a table).- Tests by hydrostatic pressurc, by S. Loyd Wiegand, M.E.-Velocity of approach in weir computations, by A. W. Hunking and Frank S. Hart (with tables).-The earth's ellipticity, by I. D'Auria. - Suggestions for the improvement in the manufacture of glass, by George W. Holley.-Survey of the future water-supply of Philadelphia, by Rudolph Hering, C.E.Influence of high pressure on living organisms. - Atmospheric changes at Nice.-Bernauf's telescope.-Microscopic organisms on the surface of coins. - Magnetism in Madagascar. - Selective absorption of solar energy.-Use of oxygen as a refrigerant.

Annalen der Physik unt Chemie, No. 8, Tuly r.-On a new method of determining the vapour-densities of bodies with a low boiling-point, by Nik. von Klobukow (Io figures and a table). - On a new method of determining the vapour-densities of bodies with high boiling-points, by Nik. von Klobukow (7 figures). - On the influence of pressure on the viscosity of liquids, particularly of water, by W. C. Röntgen ( 2 figures and 2 tables). - On the 